Revue bibliographique pour le domaine irano-aryen

\title{
George Lane. «Persian Notables and the Families Who Underpinned the Ilkhanate »
}

\section{Denise Aigle}

\section{(2) OpenEdition \\ 1 Journals}

\section{Édition électronique}

URL : http://journals.openedition.org/abstractairanica/46410

DOI : 10.4000/abstractairanica.46410

ISBN : 1961-960X

ISSN : 1961-960X

Éditeur :

CNRS (UMR 7528 Mondes iraniens et indiens), Éditions de l'IFRI

Référence électronique

Denise Aigle, « George Lane. «Persian Notables and the Families Who Underpinned the Ilkhanate » », Abstracta Iranica [En ligne], Volume 37-38-39 | 2018, document 4, mis en ligne le 30 décembre 2018, consulté le 01 octobre 2020. URL : http://journals.openedition.org/abstractairanica/46410 ; DOI : https://doi.org/10.4000/abstractairanica.46410

Ce document a été généré automatiquement le 1 octobre 2020.

Tous droits réservés 


\title{
George Lane. « Persian Notables and the Families Who Underpinned the Ilkhanate »
}

\author{
Denise Aigle
}

\section{RÉFÉRENCE}

George Lane. «Persian Notables and the Families Who Underpinned the Ilkhanate » in Reuven Amitai \& Michal Biran (eds). Nomads as Agents of Cultural Change. The Mongols and Their Eurasian Predecessors. Honolulu: University of Hawaii Press, 2015, p. $182-213$

1 Dans cette article, G. Lane cherche à briser les différences culturelles manifestes entre Mongols et Persans sous les Ilkhans au XIII ${ }^{\mathrm{e}}$ siècle. Il considère que ce qui a été perçu comme un gouffre culturel a été compensé par la tradition consistant à faire collaborer les élites mongoles et persanes, comme cela avait été le cas sous les Seldjoukides. Cette thèse doit être néanmoins un peu nuancée. Dans Émirs mongols et vizirs persans dans les remous de l'acculturation, l'option prise par Jean Aubin n'est pas d'étudier les relations entre Mongols et Persans comme des rapports entre modèles de civilisation, mais en termes de relations entre hommes. Il trace l'histoire mouvementée du vizirat, faite de purges et d'éliminations physiques brutales. Les deux élites sont inégales de condition. S'il est vrai que les Persans sont victimes de l'ingratitude des Mongols qui «sur la calomnie d'un malfaisant, foulent aux pieds cinquante années de services » (p. 81), bien plus sanglantes, ont été les coupes sombres dans les rangs des émirs. Les sources désignent ces derniers par une expression d'une réelle exactitude: «gibiers des sabres » (shikār-i suyū $)$. 


\section{AUTEURS}

DENISE AIGLE

UMR 8167 - Orient et Méditerranée 